ROCZNIKI TEOLOGICZNE

Tom LXVII, zeszyt $12-2020$

DOI: https://dx.doi.org/10.18290/rt206712-1

REV. IONIŢĂ APOSTOLACHE

\title{
"I WANT TO LIVE FOR IMMORTALITY": FYODOR MIKHAILOVICH DOSTOEVSKY IN SEARCH OF GOD
}

\begin{abstract}
A bstract. Fyodor Mikhailovich Dostoevsky is one of the most important Christian writer in $19^{\text {th }}$ century Russia. His works develop images, typologies, thought patterns and existential interpretations. In our present research we try to emphasise the confessional elements of Dostoevsky's existential thinking. Starting from a brief biographical presentation, we discover the Christian value of his message; which, always ciphered with types and symbols, actually represents a valuable Christian confession and apology, in reference to the concrete sense of existence. In this regard, this great Russian writer speaks of an earthly existence, burdened with personal sins and passions, liberated by faith in God. Therefore, we have tried to analyse, from the apologetics perspective, the problem of liberty from his "Legend of the Great Inquisitor," a magisterial chapter from his masterpiece Brothers Karamazov.
\end{abstract}

Key words: apologetic; Christian existentialism; Dostoevsky; "Legend of the Great Inquisitor"; liberty; Karamazov Brothers; Russia.

The issue on existence, characterized by various interpretations, is an essential topic for such areas as theology, philosophy, sociology, genetics, anatomy, politics, history, philology or law. Man, with all his daily concerns, is as once an image and typology for philosophers and psychologists, and also an icon of the Heavenly Father, imprinted in eternal universe.

Rev. Ioniță Apostolache, PhD - Associated Professor at the University of Craiova, Faculty of Orthodox Theology, Romania. His scholar interests focus on apologetics and Syriac theology. $\mathrm{He}$ is an Orthodox priest from the diocese of Craiova, at the Obedeanu Church (Romania); address for correspondence: Str. Brestei 24, Craiova, Romania; e-mail: nutuapostolache@ yahoo.com. ORCID: https://orcid.org/0000-0002-8722-6998.

Ks. dr IoniȚĂ Apostolache - Profesor nadzwyczajny na Uniwersytecie Craiova, Wydział Teologii Prawosławnej, Rumunia. Jego zainteresowania naukowe obejmują apologetykę i teologię syryjską. Jest prawosławnym duchownym z diecezji Craiova w Kościele Obedeanu (Rumunia); adres do korespondencji: Str. Brestei 24, Craiova, Rumunia; e-mail: nutuapostolache@ yahoo.com. ORCID: https://orcid.org/0000-0002-8722-6998. 
There is a very special "icon" of man that has masterfully illustrated the natural existential reality for almost two centuries. It has been said that Man is the embodiment "of an antithetic personality in the history of universal literature," whose work defines "the changing and broad layers of the human soul." "Torn conscience, ruled by antitheses, characterized by great indecisions, from topical socialism to the mysticism of orthodoxy which aims at the liberation of man from social and moral evil in atonement through sacrifice and humility," Fyodor Mikhailovich Dostoevsky was not only one of the greatest Russian novelists and essayists, but also a singular representative of the existentialist movement. ${ }^{1}$

Born on October $30^{\text {th }}, 1821$, in the great city of Moscow, Dostoevsky was the son of a noble family. With an interest in and talent for letters and literature, Fyodor instantly succeeded in understanding the great themes of writers such as Homer, Goethe, Schiller, Hoffmann, Moliere, Voltaire, Balzac, Shakespeare and Dickens. Inhaling this wonderful nectar of wisdom, he soon realized that he was made only for words. His concern for literature became his modus vivendi. The art that moulded his great literary gift transformed him so as to become "the most thoughtful thinker of the nineteenth century. His vision on the world, of a great modernism, was a source of inspiration not only for the existential philosophy, but also for psychoanalysis and theology."2

There were several 'crossroad' moments in his life, which caused a fundamental life-change and which led him to discovering the saving truths of a Christian existence. Religiously indifferent in his early life, and touched by "several traumas," young Dostoevsky miraculously managed to avoid execution (December $22^{\text {nd }}, 1849$ ) along with four salt works in Siberia (18501854), and then finding his talent for writing which led to the creation of his undeniable legacy. He published a great number of papers in the most famous literary journals of tsarist Russia, but the most creative years were to be his last fifteen, when his most important novels were published: Crime

${ }^{1}$ Gabriela Dantis, Scriitori străini [Romanian Writers] (București: Editura Ştiinţifică şi Enciclopedică, 1981), 159.

${ }^{2}$ Ivan IvlampIE, Spiritualitualismul rus in secolul $X X$ [Russian Spiritualism in the Twentieth Century] (București: Editura Eikon, 2015), 61.

${ }^{3}$ Bearing in mind his "Moscow childhood, most of the time spent in his father's hospital because of his illness-like nature; his tragic boarding school years; enrolment, together with his brother Michael, in Sankt Petersburg Engineering Military School." Ciprian Iulian ToroczKay and Daniela PREDA, ,Lumini şi umbre: «paradoxul Dostoievski» sau între ateism şi credinţa în Iisus Hristos [Lights and Shadows: «Dostoevsky as a Paradox» or between Atheism and Faith in Jesus Christ]," Theological Review 2016: 123-124. 
and punishment (1866), The Idiot (1868), Demons (1871), The Adolescent (1874-1875) and his masterpiece The Brothers Karamazov (1880). ${ }^{4}$

Due to its profound existentialist-Christian value, Dostoevsky's great literary work has become a true encyclopaedia of typologies, relationships, failures and perspectives that is readily recognised in contemporary human society. "Freedom and irrationality" are his chief concerns in relation to mankind. This fascinating existential paradox is to be identified throughout his novels, and is best illustrated by the typology of his characters. The modernism of his thought is remarkable, precisely because, beyond the romantic event, there lies deep truth and meaning. In a grey world, "salvation takes place due to the rediscovery of the divine image in each of us: healing is entirely spiritual." Basically, Dostoyevsky's great thought is firmly impelled by evangelical spirit, which posits that the only way to salvation is personal virtue and faith in the Saviour Christ. "Virtuous man becomes an angel, the evil one beast - Dostoevsky writes. It was nails and not love that Kept Jesus on the cross! (His sacrificial love that saves us). There is a spiritual fight: Life is God's battle with the devil, and I am the battlefield. And what a war! Faith is the altar of soul: How dreadfully has it tormented me (and torments me even now) this longing for faith, which is all the stronger for the proofs I have against it. And yet God gives me sometimes moments of perfect peace; in such moments I love and believe that I am loved; in such moments I have formulated my creed, wherein all is clear and holy to me. This creed is extremely simple; here it is: I believe that there is nothing lovelier, deeper, more sympathetic, more rational, more manly, and more perfect than the Saviour; I say to myself with jealous love that not only is there no one else like Him, but that there could be no one. I would even say more: If anyone could prove to me that Christ is outside the truth, and if the truth really did exclude Christ, I should prefer to stay with Christ and not with truth."

The messages of Dostoevsky's novels usually focus on a biblical subject. In this way, by his classic typologies, he permanently seeks to identify and relate genuine created existence to the spiritual purpose of life. For instance, in his novel "Crime and punishment" the message the author wanted to transmit is related to the miracle on "The raising of Lazarus of Bethany": in "Demons" we are referred to "the healing of the demonized from Gher-

\footnotetext{
${ }^{4}$ Ibid., 109.

5 "Feodor Dostoievski: Nu e nimic mai frumos decât Hristos! [Fyodor Dostoyevsky, Nothing is More Beautiful than God!]," 24PHarte, accessed 1 Jan. 2020, https://24pharte.ro/feodordostoievski-nu-e-nimic-mai-frumos-decat-hristos/.
} 
ghesa" and last but not least, his masterpiece The Brothers Karamazov reminds us of the words of the Saviour in the Gospel of John: "Very truly I tell you, unless a kernel of wheat falls to the ground and dies, it remains only a single seed. But if it dies, it produces many seeds." ${ }^{6}$ In other words, Professor Ion Ianosi ${ }^{7}$ wants to demonstrate the fact that "the parable of the grain of wheat, which dying bears fruit, actually transgresses all of Dostoevsky's work; it is a complete yet terse symbol of the novelist's belief that happiness is gained in pain, greatness springs out of humility, death (physical or spiritual, real or symbolic) goes beyond true life. The words of John the Evangelist describe not only Dimitri and Alexei Karamazov's misery, but also Sonia Marmeladova, Sofia Andreieva and Prince Mishkin's torment and Raskolnikov, Satov and Versilov's final salvation." 8

\footnotetext{
${ }^{6}$ John $12: 24$

${ }^{7}$ Ion Ianosi, professor of philosophy and aesthetics, his original name Ioan-Maximilian Steinberger was born into a Jewish family in Brasov on May $1^{\text {st }}, 1928$. He faced a challenged existence since from 1940 to 1944 he was taken away the right to learn based on the fact that he was a Jew. However, since he was quite an ambitious character, he first attends a vocational school and manages to socially rehabilitate himself, embracing the communist doctrine. As a member of the communist party and having his new name (Ianosi) as an armour, he attends the courses of the University of Cluj. A student with special intellectual capacities, Ioan Ianosi is sent to attend the courses of the Faculty of Philosophy in Saint Petersburg, Russia (1949-1953), where he graduates as a valedictorian for all Jdanov University. In 1955 he began his $\mathrm{PhD}$ studies, choosing Aesthetics as specialization. He completes the project in record time (one year), this being the beginning of an outstanding "activity as a writer and teacher, helping as a publishing reviewer to the publication of a number of works considered «difficult» at that time (The Journal from Paltinis, Book of Letters etc.)." The great professor of philosophy and aesthetics "was one of the highest representatives of the Romanian culture since he organized the World Congress of Aesthetics in Bucharest in 1972. He was a pen friend and built friendships and collaborations, over time, with a great number of Romanian writers or theorists, including Belu Zilber, Constantin Noica, Henri Wald, Alexandru Dragomir, Radu Cosasu, Gabriel Liiceanu or Zigu Ornea. $\mathrm{He}$ is the author of a great number of works and papers on philosophy, aesthetics, literary history, monographs and memorials, where speculation soberness combines with tolerant generosity of interpretation. Studying the history of ideas and mentalities, Ianosi's essays generally advocate for shades and analysis, opposing to thought Manichaeism which had, for the history of the twentieth century in particular, a disastrous ideological and practical consequences. For over four decades, Ion Ianosi was a professor of philosophy and aesthetics at the Faculty of Philosophy of the University of Bucharest. In 2001, he became an honorary member of the Romanian Academy" - see here: Ion IANOSI, O viață de cărturar [A Life of a Scholar] (București: ALL Educational, 1998); Estetică și moralitate: Omagiu profesorului Ion Ianoși la 70 de ani de viață (culegere de studii și profil spiritual) [Aesthetics and Morality: Tribute to Professor Ion Ianosi fort his 70 years of life - a collection of studies and spiritual profile] (București, Editura Crater, 1998); Ion Ianoşi-80/Ion Ianosi-80 (București: Editura Europress Group, 2008).

${ }^{8}$ Ion Ianosi, Dostoievski-Dostoievski. Tragedia subteranei; Dostoievski şi Tolstoi. Poveste cu doi necunoscuţi [Dostoevsky - Dostoevsky. The Underground Tragedy; Dostoevsky and Tolstoy: Story with Two Strangers] (București: Editura Universitas, 2000), 221.
} 


\section{"THERE IS SOMETHING STRANGE IN DOSTOEVSKY'S PERSONALITY"}

The great Nichifor Crainic $(1889-1972)^{9}$ noted in one of his lectures: "This type of peculiarity is actually to be identified in all geniuses: suggesting that this type of person is beyond the normal, that is, he is exceptional, and has nothing to do with the common way we regard man. As for Dostoevsky, however, the peculiarity of his genius is a complex by reason of the fact that Dostoevsky was a sick person, with an epileptic one." ${ }^{10}$ According to most critics, however, Dostoevsky's malady is the source of his religious inspiration. Based on this information, the type of realism for which Fyodor Mikhailovich Dostoevsky advocated turns into a magical realism. In other words, his profound message goes beyond reality's practical limitation, while maintaining its original features. Nichifor Crainic draws a suggestive comparison, when he compares the material which Dostoevsky uses in his works with iron. "At normal temperature, Crainic writes, iron is of the colour you know, grey-iron. When immersed at a certain temperature, iron gets red. But under the action of a higher temperature, iron gets white. Therefore, it gets a more and more immaterial colour, I could say, under the flame's increasing action and temperature... This power, quite amazing, first to distort reality and then to transform it and confer other features, but identifying in those fantastic-like features reality's basic directions, we identify in Dostoevsky's literary works. Therefore, when reading one of his novels, do not be surprised to find that you suddenly get access to an almost fantastic world. He is not what is literally called 'a fantasy novelist,' who, unlike Jules Verne fantasizes broadly on certain topics. He is a fantasy realist, in the real sense of life, his rhetoric bearing

\footnotetext{
${ }^{9}$ Nichifor Crainic's interest for F.M. Dostoevsky's literature is mainly related to a series of lectures given for two years (1926-1928) in the Faculty of Theology in Chisinau. He once again remember his interest for the Russian writer from 1932 to 1933, when he taught a course under the title Dostoievski şi creştinismul rus [Dostoevsky and the Russian Christianity], for the students of the Faculty of Theology in Bucharest, in the third and fourth years. Briefly, about Nichifor Crainic, father professor Dumitru Staniloae used to say that "he is the first Romanian theologian in the modern era of our history who takes theology out of the narrow and bypassed circle of specialists and submits it, in a magnificent way, to the attention of the scholarly world... Nichifor Crainic renews by modernizing tradition in a theology that was satisfied with a few crumbs of this tradition, often received and many times through bypassed interpretation of the Western theologies, achieving 'a true restoration of the Romanian theology in the orthodox spirit'." Thinking, no. 4, Apr. 1940; see also "Note on the edition" in the work of Nichifor CRAINIC, Dostoievski şi creştinismul rus [Dostoevsky and the Russian Christianity] (București: Editura Anastasia, 1998).

${ }^{10}$ Ibid., 54.
} 
the seal of his genius - melting, warming it at the high flame of his genius conferring a completely different appearance, still without annihilating its original nature" ${ }^{11}$. Therefore, Dostoevsky's great genius is marked by Christian existentialist value which can be observed in his characters. This is very evident in his trilogy: The Idiot, Demons, and The Brothers Karamazov.

The novel The Idiot was begun in Geneva in September $14^{\text {th }}, 1867$, and was completed in January $17^{\text {th }} 1869$, in Florence. Composing this great novel proved to be a very difficult undertaking: the author even abandoned the first draft. He expressed his frustration with the lack of achievement, "expressing less than $10 \%$ of what he wanted to convey, although I do reject it and I still love my idea up to the present moment."12 The Idiot is priceless literary masterpiece, which displays a wide range of "increasingly troubled characters." The hero, Prince Nikolai Mishkin, "undertakes, as a personal mission, the salvation of this human being smashed by the world he lives in, a world ruled by the prevailing power of money and ordinariness dominance" $"$. He is "the image of Christ ... The very presence of Prince Mishkin, after many years spent somewhere in the far away mountains, far away from people, should remind about descent of Christ among people, in their lives, crushed by poor passions, devilishly complex."14 Dostoevsky's hero is at this point "the philokalic man, in the sense that he is by definition a man who loves the beautiful; he is the man who lives in order to identify the beautiful anywhere in the world and to reveal to others, as well. The meaning of his life is the restoration of the image of Christ in all those close to him, by identifying beauty even where, having fallen into the abyss of a corrupt society wholly possessed by avarice and turpitude, it is hardly identifiable" 15 . Therefore, Dostoyevsky's Idiot is not merely an idiot, but he is what we might call evangelically "poor in spirit," "a model of Christian, following the ultimate and undeniable model of the Holy Gospel."16

The second novel analysed here is Demons. Published on November $21^{\text {st }}$, 1961, the work actually illustrate the Russian writer's contemporary dark

\footnotetext{
${ }^{11}$ Ibid., 51.

${ }^{12}$ IANOSI, Dostoievski [Dostoyevsky], 87.

${ }^{13}$ Nicoleta-Ginevra BACIU, Isihasmul in reflexii literare: Tolstoi, Sadoveanu, Dostoievski [Hesychasm in Literary Insights: Tolstoy, Sadoveanu, Dostoevsky] (Bucuresti: Editura Paideia, 2014), 273.

${ }^{14}$ Vladimir V. ERmiLov, Fyodor Dostoyevsky, 1821-1881 (Foreign Languages Publishing House, 1959), 247.

${ }^{15} \mathrm{BACIU}$, Isihasmul in reflecţii literare [Hesychasm in Literary Insights], 284-285.

${ }^{16}$ CRAINIC, Dostoievski şi creştinismul rus [Dostoevsky and the Russian Christianity], 87-88.
} 
and imminent "atheism." Similarly, as in The Idiot, the writer employed a wide range of his problematic characters to highlight, bright images and figures, such as, for example Bishop Tihon. The main idea of the novel espouses the moral, according to which, "man generally speaking lacks the vocation of evil up to the wayand that even the most tenacious of those admitting it must at one point abandon the dreadful race they got caught into." 17 Caught into the classic saga of eternal return to God, ... Bishop Tihon must first face the atheist challenge. ${ }^{18} \mathrm{He}$ points out the fact that "the perfect atheist finds himself on the step preceding perfect faith." In his opinion, the worst issue is that of religious disinterest, the condition when man "has perverted to the lowest level the image of God bestowed upon him when created." Therefore, "two types of atheists can be distinguished: the decision making ones (the ones who 'killed God,' according to Nietzsche, that is, 'the fighters' against God, the active ones) and the careless ones (labelled by Dostoevsky as 'the half-measure men,' i.e. the ones who do not even question the existence of God, the passive ones). For the Russian writer, where Stavroghin falls the latter are the more guilty. Others like him will never be able to cross the line that separates evil from good (for as it is possible to ascend (decesnd?) (or ascend from evil to good) from good to evil, from disbelief to faith, according to the principle 'opposites attract'): 'I did not understand ... nor did I feel Good or Evil,' Stavroghin says." "19

Therefore, the novel Demons is clearly marked by a confessional and prophetic value, which may be considered as a foreword to the atheist Bolshevik regime, which was to rule Russia. Dostoevsky's attitude is therefore a rebellious one, against religious carelessness and atheistic nihilism. Professor Ion Ianosi relevantly notices the fact that "Demons is to be interpreted as a 'movement novel,' directed against nihilistic trends - wholly negative ones, of socialist / communist direction - , but of an artistic power which can not be compared to many other anti-nihilistic novels of the time. This time, the partisan attack against the targeted partisanship reaches its highest level of success. No other nineteenth century novel had so deeply forecast the mechanisms of the totalitarian dissolution of the twentieth century; and the Stalinist ideologues, who stubbornly refused to face reality, completely

\footnotetext{
${ }^{17}$ Valeriu CRISTEA, Tânărul Dostoievski [Young Dostoevsky] (București: Editura Cartea Romaneasca, 1971), 12.

${ }^{18}$ We can consider at this point the conversation between Bishop Tihon and Stavrohin on the arguments of faith in God.

${ }^{19}$ ToroczKay and PredA, "Lumini şi umbre [Lights and Shadows]," 128.
} 
and brutally rejecting the prophecies of the novel, should at least admit the error, for the benefit of shadowed judgments." 20

We now turn to analyse Dostoevsky's third and very well-known novel, The Brothers Karamazov. Concerning the existentialism for which the writer advocated, this work is "the last chapter of such great proportion; a chapter meant to sum up all main topics and ideas illustrated by the previous sections of the work and to complete the typological families of characters, already present within the astronomical text, due to key, unforgettable character, imagined beyond time and historical determinations of all kinds." 21 Here, through the image of the spiritual Father Zosima, Dostoevsky succeeds in offering a masterly description of the main Russian spirituality philokalic guidelines. In fact, he points at the great Païssy Velitchkovsky, the founder of new Hesychasm, the restorer and reformer of Hesychastic traditions, among which "the tradition of abbots is first ranked." Therefore, he offers accompanying notes such as: "It was revived among us towards the end of last century by one of the great 'ascetics,' as they called him, Païssy Velitchkovsky, and his disciples. But to this day it exists in only a few monasteries, and has sometimes been almost persecuted as an innovation in Russia. It flourished especially in the celebrated Kozelski Optin Monastery. When and how it was introduced into our monastery I cannot say. There had already been three such elders and Zossima was the last of them. But he was almost dying of weakness and disease, and they had no one to take his place." ${ }^{22}$

Together with his spiritual father, abbot Zosima, Alyosha Karamazov takes part in "what might be called as a Hesychasm project. As one of his closest disciples, he is sent 'to the world to reconcile and unite people.' He bears within in his most inner essence, one of Christianity's most essential principles: never judge anyone, a reason why everyone feels good around him and confesses. When Zosima dies, his faith shattered in his soul, but then, his belief that love (about which his abbot used to preach) is stronger than death wins and Alyosha, remained faithful to his and his abbot's ideals, advocating for active love in the world, it still remains a promise of luminous evolution, in a remarkable novel, which has never been written before. He is entrusted by his spiritual father to a brilliant monk, who stands out in the novel as a de-

\footnotetext{
${ }^{20}$ IANosi, Dostoievski [Dostoyevsky], 135.

${ }^{21} \mathrm{BACIU}$, Isihasmul in reflecţii literare [Hesychasm in Literary Insights], 330.

${ }^{22}$ Feodor Mihailov DostoIEvski [Fyodor Mikhailovich Dostoevsky], Fraţii Karamazov [The Brothers Karamazov], trans. Ovidiu Constantinescu (București: Editura Pentru Literaturá Universala, 1965), 37-38.
} 
fender of the new monastic order and whose name is Paisie (as Païssy Velitchkovsky), while his later evolution as one of Dostoevsky's fascinating characters is something like a mystery that we will never be able to grasp" ${ }^{\text {"23. }}$.

Viewed from an holistic approach, Dostoevsky's masterpiece The Brothers Karamazov" comprises "an apotheosis vision" in the way Dostoevsky sees Russia. "This novel, Nichifor Crainic argues, Dostoevsky's vision on the three Russias is illustrated: a normal Russia, where good and evil coexist, mixed without any complete awareness of what to do and what not to do. This normal Russia is illustrated by Dimitri's passions. Then there is the other Russia, the scholarly one, but it is perverted by the rationalist and political philosophical idea, the revolutionary one, that one which is also illustrated in the novel Demons whose representative becomes here Ivan Karamazov. The two heroes of the novel, Dimitri-normal Russia and Ivan - perverted scholarly Russia, do not end well: one ends up in prison and the other gets mad. Only one hero succeeds in saving himself at the end of the novel, and that is Alyosha, fully prepared to carry on his shoulders the great mission of Christianity, which abbot Zosima planted in his soul. This emblematic Alyosha, actually stands for everything that Dostoevsky could imagine about a better future Christian world and society, about a reborn Russia, saved by the gospel's value."24

\section{NIKOLAY BERDYAEV ON "DOSTOEVSKY'S PHILOSOPHY”}

Closely linked to Dostoevsky's existentialist vision, the great Russian thinker Nikolay Berdyaev draws up a remarkable philosophical exegesis focused on the coordinates of his thinking. Dostoevsky's philosophy" is thus a true "pneumatological" assessment of Dostoevsky's dialectics.

In the world of Fyodor Mikhailovich's ideas, the well-known critic discovers "a true feast of thought," comprising the teaching about the world, about man, about the dynamics of existence and social becoming, about the absence, lack, abstract or necessity of rediscovering faith in God. His genius can hardly be compared to anything, and it can be by far compared to "Shakespeare, the brilliant mind of the Renaissance." The reader discovers in his creations "a new world," which "restores man his spiritual wits." This spiritual salvation has a "religious-church start" and is based upon "a return

\footnotetext{
23 Ibid.

${ }^{24} \mathrm{BACIU}$, Isihasmul în reflecţii literare [Hesychasm in Literary Insights], 355.
} 
to oneself, towards spiritual depths, towards spiritual experience, it means giving back man his own spiritual depth, a part in this closed 'virgin-like' 'psychological' reality." For the Russian novelist, "man is not just a mere 'psychological' being, but also a spiritual one. Spirit is not something external to man, but something internal, 'the place he discovers Christ' through affliction and freedom.

In the exegesis carried out for his great predecessor, Nikolay Berdyaev identifies a series of favourite topics on which "Dostoevsky's Philosophy" focuses upon. The first is "man." Actually, this is a confirmation of his preference for Christian existentialism, a topic that is present in Berdyaev's thought also. Therefore, Dostoevsky's man is “a microcosm, existential centre, the sun around which all orbit. Everything is within man and for man. The mystery of universal life lies in man. To clear up the issue of man means to clear up the issue of God." 26 The wide range of his descriptions, greatly mastered in his novels for all of his characters, positively illustrates this characterisation. Moreover, his anthropology sometimes becomes a "Hesychastic one." ${ }^{, 27}$ In the first part of his novel The Brothers Karamazov, there is a very interesting chapter, entitled "Elders." At the outset we consider Alyosha's integration in the context of a search which finally proves positive from the perspective of a necessary rediscovery of faith of man in general. The following is an illustration of such a text: "I shall be told, perhaps, that Alyosha was stupid, undeveloped, had not finished his studies, and so on. That he did not finish his studies is true, but to say that he was stupid or dull would be a great injustice. I'll simply repeat what I have said above. He entered upon this path only because, at that time, it alone struck his imagination and presented itself to him as offering an ideal means of escape for his soul from darkness to light." 28

The topic about man's existence is incomplete without considering the gift of freedom. In a broader context, starting from individual freedom Dostoevsky quickly creates a bridge between this and universal freedom. "All his novels are tragedies of human freedom. Man begins to exert his freedom intensely, regardless any suffering, madness, only to feel himself free. At the same time,

\footnotetext{
${ }^{25}$ Nikolai Berdiaev [Nikolay Berdyaev], Filosofia lui Dostoievski [Dostoevsky's Philosophy], trans. Radu Pârpauța (Iaşi: Institutul European, 1992), 22-23.

${ }^{26}$ Ibid., 24.

${ }^{27}$ BACIU, Isihasmul în reflecţii literare [Hesychasm in literary insights], 257.

${ }^{28}$ Feodor Mihailov DostoIEvski [Fyodor Mikhailovich Dostoevsky], Fraţii Karamazov [The Brothers Karamazov], trans. Ovidiu Constantinescu (București: Editura Polirom, 2011), 38.
} 
he longs for ultimate, absolute freedom." ${ }^{29}$ There is, therefore, a path to freedom along which the pilgrim can either rediscover himself or get lost. On the true way, He who is "The Way, the Truth and the Life," 30 offers Himself, so that through Himself man can reach true freedom." Christ, Berdyaev emphasizes, represents what it really means to be a good Christian, the whole meaning of the act of faith is an act of freedom. To be a man means the acknowledgement of two types of freedom: the freedom to choose between good and evil, and freedom for good; freedom in choosing the Truth and freedom for the Truth." 32 It is notable at this point to refer to the way Dostoevsky imagined his characters living in the relationship between freedom and grace. From a rational point of view, this is an issue which is rather delicate and difficult to explain. However, the Russian novelist's existentialist approach extracted "precisely from life creation, courage, from the divine nature of life itself. His thought grows instantly, like a steam rising from the fresh, lively heat of life. It is not a thought meant to point out rational formulas, as if created in a philosophy room. Therefore, these issues about external freedom, or freedom without grace, are for him dilemmas of life itself and not of philosophy. For him, philosophical issues get their resolution in the deeds the heroes do." 33

Evil is another major influence in the evolution and development Dostoevsky's thinking. Evil is a consequence of freedom, without which it is rootless. In other words, he thinks that "freedom reaching arbitrariness, leads to evil, evil - to crime, crime - unavoidably, to punishment." Punishment materializes in suffering. Facing countless life challenges, Dostoevsky never ceased to be "a sentimental humanist, sweet and weak." His belief was that suffering possesses above all else, "the power to save." Although suffering is related to evil and evil is related to freedom, the "path of freedom" is always the "path of suffering" also. This is coupled with the insight that without freedom, "there is no suffering at all." Nevertheless, Dostoevsky is an "advocate for freedom" and this is the reason why "he asks man to accept suffering as a natural outcome. Dostoevsky's harshness is linked to this way of conceiving freedom to all costs." 34 Therefore we have the great "Legend of the Grand Inquisitor," which we are now to analyse.

\footnotetext{
${ }^{29}$ Berdiaev [Berdyaev], Filosofia lui Dostoievski [Dostoyevsky's Philosophy], 42.

${ }^{30}$ Cf. John 14:6.

31 "The truth will set you free" (cf. John 8:32).

${ }^{32}$ Berdiaev [Berdyaev], Filosofia lui Dostoievski [Dostoyevsky's Philosophy], 43.

${ }^{33}$ Crainic, Dostoievski şi creştinismul rus [Dostoevsky and the Russian Christianity], 103-104.

${ }^{34}$ Berdiaev [Berdyaev], Filosofia lui Dostoievski [Dostoyevsky's Philosophy], 69-70.
} 
The existentialist pictures created by these interconnections, conclude with a great exaltation that Dostoevsky dedicates to suffering. Hence, the most important topic of his novels, namely "love" ${ }^{35}$ is derived. It is Christian love that always makes suffering worthwhile and gives meaning to it. We should remember the event during which Abba Zosima sends his apprentice, Alyosha, to "the great service of the world." Having reminded him of the words of the Lord, ${ }^{36}$ the abbot tells his disciple that "he is to endure much until he gets back to the holy place and he is to toil a lot." In order to cast away any tempting thoughts, Abba teaches his disciple to "seek happiness in suffering." His advice is therefore both very simple and useful: "keep Christ within your being, He will help you." 37

\section{"LEGEND OF THE GRAND INQUISITOR,",38 OR ABOUT "THE BURDEN OF FREEDOM"}

According to Nikolay Berdyaev (1874-1948) $)^{39}$ this episode, perfectly illustrated by the conversation between Ivan and Alyosha Karamazov, is by

35 "It is becoming increasingly clear that if suffering and disease did not exist, they should be invented. For the world is inconceivable without suffering, without disease and living - potential sources of life and beauty. Of a certain type of beauty." Aura CHRISTI, Dostoievski-Nietzsche. Elogiul suferinţei [Dostoevsky - Nietzsche. The Apologetics of Sorrow], $2^{\text {nd }}$ edition (București: Editura Ideea Europeana, 2017), 406.

36 "In this world you will have trouble. But take heart! I have overcome the world." (John $16: 33)$.

37 "In suffering lies the idea, says Porfir to wonderer Rodion. Beauty emerged out of the underground suffering can rule the world, but it opposes to being itself ruled by the world - it is one of the key reasons about Prince Myshkin meditates, finally admitting that he is not prepared. $\mathrm{He}$, precisely he, who does everything that's in his power to turn the into chance and speaks, as if he were taking, each and every moment an exam in front of the whole Universe. Just as Prince Myshkin, Alyosha Karamazov faces the impossible, as if he were standing in front of a wide open door. It is enough to follow the way the two heroes use the 'living material' around them, to be astonished at the gates of impossibility to change it, their efforts to continue their great stubborn work troubling any human being." CHRISTI, Dostoievski-Nietzsche. Elogiul suferinţei [Dostoevsky - Nietzsche. The Apologetics of Sorrow], 408.

${ }^{38}$ Dostoievski [Dostoevsky], Fraţii Karamazov [The Brothers Karamazov] (2011), 314-338.

${ }^{39}$ The great Russian philosopher Nikolay Berdyaev is connected to Dostoevsky through the Christian existentialism he advocates for. Based on the way he values the work of his forerunner and lacking great consistency, we could say that his ideas are largely inspired by the Dostoevsky's philosophy. He discovered Dostoevsky when he was barely 14, including him in the list of existential training lectures, together with the works of Kant, Hegel, Voltaire or Schopenhauer, Tolstoy or Soloviov were also found. The present paper is one of the most valuable assets of "Christian philosophy," derived from the work of the great novelist and thinker of Russian 
far the "peak of Dostoevsky's work" and "the crown of his dialectics." This emblematic image, meant to be a gift for human freedom and spirit, "is still a mystery up to day. It is uncertain which side takes the one telling the Legend and which side takes the writer himself." What is certain is the fact that, its most profound interpretation is due to "human freedom." It defines a critical moment, a prophetic one when man must choose the immutable path of his existence: together with Christ or without Christ and all alone. As a result, when confronting a "legend of freedom," it must definitely approach freedom. "Light lights darkness. In the rebellious soul of the atheist Ivan Karamazov worship for Christ dwells. Man's destiny unwillingly pulls him either in the direction of the Grand Inquisitor or of Christ. He must inevitably make a choice. There is no third option. The third is only a passing condition, a barely clear state of the final obstacles. In the Grand Inquisitor's system, free will only will result into losing and denying the freedom of spirit. And freedom can be achieved only through Christ." ${ }^{40}$ On the other hand, the message Dostoevsky wished to convey, grounded as we have already noticed on the value of human freedom and spirit, is generally illustrated and it transforms into an acid analysis of historical Catholicism and atheist socialism, which was just on the edge of emerging.

Therefore, the event which takes place in The Brothers Karamazov is imagined as a conversation between Ivan and Alyosha, on "the existence of God." The elder brother entitles his description or poem "The Grand Inquisitor." The plot takes place in Spain, in Seville, in the time of the Inquisition. The Saviour shows Himself in these hard times, when people were burnt at the stake as heretics. His apparition is before the Parousia (His second coming), and is thought to be only a temporary one. Being aware of the fact that he is the Lord, the crowds begin to agitate, to gather around Him, and He blesses them and heals the sick, even raising a child from the dead. The Grand Inquisitor shows up instantly, accompanied by soldiers and $\mathrm{He}$ is being arrested. In the dungeon, enchained, Christ is subjected to a deaf trial; from his mouth only silence can be heard. The inquisitor asks the questions and he is also the one who gives the answers. Freedom is the main topic present in his words, driven by the fault of the possibility of its rebirth in the cells of man restored by the return of the Saviour to the world. The Inqui-

empire - see for details: Nikolai Berdiaev [Nikolay Berdyaev], Cunoaşterea de sine. Exercitiu de autobiografie filosofică [Self-knowledge. An Essay in Autobiography], trans. Inna Cristea (București: Editura Humanitas, 1998).

${ }^{40}$ Berdiaev, Filosofia lui Dostoievski [Dostoievski’s Philosophy], 124-125. 
sitor's reaction is an extreme one: since He has come into the world to give man back the gift of freedom, Christ must be this time burnt at the stake. "Why, then, art Thou come to hinder us? For Thou hast come to hinder us, and Thou knowest that. But dost Thou know what will be to-morrow? I know not who Thou art and care not to know whether it is Thou or only a semblance of Him, but to-morrow I shall condemn Thee and burn Thee at the stake as the worst of heretics. And the very people who have today kissed Thy feet, to-morrow at the faintest sign from me will rush to heap up the embers of Thy fire. Knowest Thou that? Yes, maybe Thou knowest it."41

The Grand Inquisitor's nihilistic discourse has nothing to do with Christ and the gift of His freedom, but claiming a closeness to the Antichrist. Dostoevsky considers this spiritual crash as the absolute failure of CaesarPapist Catholicism. Therefore, Nikolay Berdyaev points out the fact that "the secret of the Grand Inquisitor lies in the fact that he is not with Christ, but with him: 'We are not with You, but with him, is this all of our secret?' The spirit of the Great spirit, who replaced Christ with the Antichrist, was broadly and generally interpreted over the years. The Catholic system of Caesaropapism, which turns the Church into a political state, is, for Dostoevsky, one of the representations of the Grand Inquisitor's spirits. ${ }^{42}$ The same spirit can be identified in Byzantine Orthodoxy, in any Caesarism or imperialism. But the state, which admits its limitation, is not something typical to the Grand Inquisitor; it does not hinder freedom of the spirit. Throughout its historical existence, Christianity has always been under the temptation to give up to the freedom of the spirit. It has not been easy for Christian humanity to preserve Christian freedom and integrity. Indeed, nothing has ever tortured or torment man more than freedom." ${ }^{43}$

The Inquisitor's arguments relate to the three temptations in the desert of Karantan, firmly reprimanding their rejection by Christ the Saviour. By the

\footnotetext{
${ }^{41}$ Dostoievski [Dostoevsky], Fraţii Karamazov [The Brothers Karamazov] (2011), 319.

42 "Keeping our reserved attitude once again with regard to the criticism when he fiercely opposes to Catholicism, we must note that in regard to Western culture, seen as a whole, Dostoevsky's criticism is right. Not with regard to Catholicism in particular, but with regard to Western culture in general, based on materialistic principles, on the materialistic principle of human independent reason. His exaggerations on Catholicism rise from the fact that his writing is a pamphlet. You know that literary speaking a pamphlet is what artistically speaking a caricature is; it is based on exaggerations; it is a type of reality expressed exaggeratedly. Undoubtedly that, as far as Catholicism is concerned, Dostoevsky's exaggerations are grounded on another reason also, as a result of its literary expression." CRAINIC, Dostoievski şi creştinismul rus [Dostoevsky and the Russian Christianity], 171.

${ }^{43}$ Berdiaev [Berdyaev], Filosofia lui Dostoievski [Dostoyevsky’s Philosophy], 130.
} 
fact that $\mathrm{He}$ rejected the devil's proposal to turn stones into bread, thus paying the price of our freedom to receive "the Word of God" as food, the Inquisitor speaks about man's sinful predilection toward the wicked, for whom he would be capable to trade his freedom. For him, "I tell Thee that man is tormented by no greater anxiety than to find someone quickly to whom he can hand over that gift of freedom with which the ill fated creature is born. But only one who can appease their conscience can take over their freedom. In bread there was offered Thee an invincible banner; give bread, and man will worship thee, for nothing is more certain than bread. But if someone else gains possession of his conscience - oh! then he will cast away Thy bread and follow after him who has ensnared his conscience." ${ }^{44}$

The second temptation, to jump from the wing of the temple is accompanied by another criticism, i.e. depriving men from miracles. Also rejecting the possibility of coming down from the cross, the Saviour offers man the chance to be free in his faith. Therefore, it is not the miracle that brings him to the knowledge of the revealed truth, but indeed the freedom of the soul in the act of faith. "Thou didst crave for free love and not the base raptures of the slave before the might that has overawed him for ever," the Grand Inquisitor says. $^{45}$

Under the offer of legal guarantees, the inquisition man is lured to melt his freedom of spirit into the legal laws of the church. Religious authority pays back the sacrifice paid in blood on Golgotha, the Grand Inquisitor thus wishing to "turn the Crucifixion into a coercive power of the world. In this way the Church always accepts the state, the sword of Caesar." 46 Actually, this is the third proposal Christ the Saviour rejected in the desert. However, "church order begins to acquire a legal aspect, Church's life is governed by some oppressive legal laws. Doesn't that mean precisely the fact that Christ must come down the cross in order to believe in Him? The irrationality of the cross, a mystery of the crucified truth, is neither evidence, nor logical or legal constraint. Christ's legal and rational truth directs freedom to con-

${ }^{44}$ Dostolevski [Dostoevsky], Fraţii Karamazov [The Brothers Karamazov] (2011), 324-325.

${ }^{45}$ Ibid., 327.

46 "We took from him Rome and the sword of Cæsar, and proclaimed ourselves sole rulers of the earth, though hitherto we have not been able to complete our work... But Thou mightest have taken even then the sword of Cæsar. Why didst Thou reject that last gift? Hadst Thou accepted that last counsel of the mighty spirit, Thou wouldst have accomplished all that man seeks on earth - that is, someone to worship, someone to keep his conscience, and some means of uniting all in one unanimous and harmonious ant-heap, for the craving for universal unity is the third and last anguish of men." Dostoievski [Dostoevsky], Fraţii Karamazov [The Brothers Karamazov] (2011), 329. 
straint. Dostoevsky remains faithful to the truth of the crucifixion, the religion of Torture, that is, the religion of freedom. And the historical destiny of Christianity has shaped this new belief. Dostoevsky's Christianity is a new one, though he remains faithful to the original Christian truth."

By Dostoevsky's development of thought "The Spirit of the Grand Inquisitor" achieves the transition from person to system, identifying the opportunity "to reveal itself for both the utmost right and left." The harmony between these two concepts self-freedom best characterizes "revolutionaries and socialists." Merciful politics for people can only encourage evil under the "mask of good." "Luring is anti-Christian in terms of nature. The anti-Christian foundation is not effortlessly traceable, it is not rough, it is a new type of evil, deceptive, elevated, it always shows disguised in good. Antichrist evil always resembles Christian good; there is always the danger of blending, of substitution. The image of good begins to duplicate, it is taken for Antichrist." 48

Dostoevsky gave a warning both for the Church and society, that people of his time ignored the "lure of anti-Christian evil." Brilliant minds, but also ordinary people, chose and accepted the situation as it was and embraced the "three lures" instead of "original freedom of the spirit." Furthermore, "Dostoevsky was the source of the spiritual-apocalyptic Russian movements. He is also the author of many types of neo-Christianity. He was the one who revealed new attractions that characterize such apocalyptic movements of Russian thinking; he foresaw the emanation of evil so subtly that it is difficult to identify it. Yet he himself was not completely free from these lures. However, what has eternal value is the approach Dostoevsky initiated: the truth about man, about fate and his freedom." 49

Concluding the present paper, we note that Fyodor Mikhailovich Dostoevsky is a true apostle of the new witnessing spirit of the Church. His ideas preserve their modernism up to the present day and have become research topics for ... Orthodox Apologetics. His anthropocentric vision gives rise to questions and yet offers solutions. Based on the various typologies we come across in his novels, Dostoevsky succeeds in illustrating in a very complex way - man's fascinating journey which starts in this world and moves towards the Kingdom of God. Freedom, however, is the most beautiful renewal of our existence with Christ the Saviour, in contrast with the rebellious spirit of the world.

\footnotetext{
${ }^{47}$ Berdiaev [Berdyaev], Filosofia lui Dostoievski [Dostoyevsky's Philosophy], 131-132.

${ }^{48}$ Ibid., 132-133.

${ }^{49}$ Ibid., 140.
} 


\section{BIBLIOGRAPHY}

Berdiaev, Nikolai [Berdyaev, Nikolay]. Filosofia lui Dostoievski [Dostoevsky’s Philosophy]. Translated by Radu Pârpauţa. Iaşi: Institutul European, 1992.

Berdiaev, Nikolai [Berdyaev, Nikolay]. Cunoaşterea de sine. Exerciţiu de autobiografie filosofică [Self-knowledge: An Essay in Autobiography]. Translated by Inna Cristea. București: Editura Humanitas, 1998.

BACIU, Nicoleta-Ginevra. Isihasmul in reflexii literare: Tolstoi, Sadoveanu, Dostoievski [Hesychasm in Literary Insights: Tolstoy, Sadoveanu, Dostoevsky]. Bucuresti: Editura Paideia, 2014).

Christi, Aura. Dostoievski - Nietzsche. Elogiul suferinţei [Dostoevsky - Nietzsche: The Apologetics of Sorrow], $2^{\text {nd }}$ edition. București: Editura Ideea Europeana, 2017.

Crainic, Nichifor, Dostoievski şi creştinismul rus [Dostoevsky and the Russian Christianity]. București: Editura Anastasia, 1998.

Cristea, Valeriu. Tânărul Dostoievski [Young Dostoevsky]. București: Editura Cartea Romaneasca, 1971.

DANTIS, Gabriela. Scriitori străinii [Romanian Writers]. București: Editura Ştiinţifică şi Enciclopedică, 1981.

Dostolevski, Feodor Mihailov [Dostoevsky, Fyodor Mikhailovich]. Fratiii Karamazov [The Brothers Karamazov]. Translated by Ovidiu Constantinescu. București: Editura Pentru Literaturá Universala, 1965.

Dostolevski, Feodor Mihailov [Dostoevsky, Fyodor Mikhailovich]. Fraţii Karamazov [The Brothers Karamazov].Translated by Ovidiu Constantinescu. București: Editura Polirom, 2011.

Ermilov, Vladimir V. Fyodor Dostoyevsky, 1821-1881. Foreign Languages Publishing House, 1959.

"Feodor Dostoievski: Nu e nimic mai frumos decât Hristos! [Fyodor Dostoyevsky, Nothing is more beautiful than God!].” 24PHarte. Accessed 01 Jan. 2020. https://24pharte.ro/ feodordostoievski-nu-e-nimic-mai-frumos-decat-hristos/.

IANOSI, Ion. O viață de cărturar [A Life of a Scholar]. București: ALL Educational, 1998.

IANOSI, Ion. Estetică și moralitate: Omagiu profesorului Ion Ianoși la 70 de ani de viață (culegere de studii şi profil spiritual) [Aesthetics and Morality: Tribute to Professor Ion Ianosi fort his 70 years of life (a collection of studies and spiritual profile)]. București: Editura Crater, 1998.

IAnosi, Ion. Dostoievski — Dostoievski. Tragedia subteranei; Dostoievski şi Tolstoi. Poveste cu doi necunoscuţi [Dostoevsky - Dostoevsky. The Underground Tragedy; Dostoevsky and Tolstoy: Story with two strangers]. București: Editura Universitas, 2000.

Ion Ianosi - 80, edited by Aura Christi and Alexandru Stefanescu. București: Editura Europress Group, 2008.

Ivlampie, Ivan. Spiritualitualismul rus în secolul XX [Russian Spiritualism in the Twentieth Century]. București: Editura Eikon, 2015.

ToroczKay, Ciprian Iulian, and Daniela PredA. „Lumini şi umbre: «paradoxul Dostoievski» sau între ateism şi credinţa în Iisus Hristos [Lights and Shadows: «Dostoevsky as a Paradox» or between Atheism and Faith in Jesus Christ]." Theological Review 98 (2016), no. 1: $123-138$. 


\title{
„CHCĘ ŻYĆ DLA NIEŚMIERTELNOŚCI”. \\ FIODOR MICHAJŁOWICZ DOSTOJEWSKI W POSZUKIWANIU BOGAY
}

\author{
Streszczenie
}

Fiodor Michajłowicz Dostojewski jest jednym z najważniejszych pisarzy chrześcijańskich w XIX-wiecznej Rosji. Jego prace rozwijają obrazy, typologie, wzorce myślowe i interpretacje egzystencjalne. W niniejszym artykule autor stara się podkreślić elementy wyznaniowe myślenia o charakterze egzystencjalnym, jakie są obecne u Dostojewskiego. Zaczynając od krótkiej prezentacji biograficznej Dostojewskiego, autor odkrywa chrześcijańską wartość jego przesłania, które zawsze zaszyfrowane symbolami w rzeczywistości reprezentuje cenne chrześcijańskie przesłanie i apologię w nawiązaniu do konkretnego znaczenia związanego z istnieniem egzystencjalnym. Pod tym względem ten wielki rosyjski pisarz mówi o ziemskim życiu, obciążonym osobistymi grzechami i namiętnościami, wyzwolonymi przez wiarę w Boga. Dlatego w niniejszym tekście autor podjął próbę apologetycznej perspektywy problemu wolności w dziele „Legenda o Wielkim Inkwizytorze”, rozdziału magisterskiego z jego arcydzieła Bracia Karamazow.

Słowa kluczowe: apologetyka; chrześcijański egzystencjalizm; Dostojewski; „Legenda o Wielkim Inkwizytorze"; wolność; Bracia Karamazow; Rosja. 